\title{
Union Is Strength: Whether BRICS Is Boon or Curse in Perspective of Global Financial and Economic Periphery
}

\author{
Arodh Lal Karn*, Rakshha Kumari Karna \\ School of Management, Harbin institute of Technology, Harbin, China \\ Email: *alkmaithili@yahoo.com
}

Received 16 May 2016; accepted 20 June 2016; published 23 June 2016

Copyright (C) 2016 by authors and OALib.

This work is licensed under the Creative Commons Attribution International License (CC BY). http://creativecommons.org/licenses/by/4.0/

(c) (i) Open Access

\begin{abstract}
One of the facts that are getting quite well known is the disappointing export performance of BRICS in recent years. What hasn't been appreciated is the fact that the extraordinary lengths of governments of Brazil, Russia, India, China and South Africa have gone to boost their exports. Hence developments in BRICS trigger numerous questions as to what one should expect the new market and institutional equilibrium to look like. Indeed initiative like capital structure, funding structure, emerging optimal benchmark portfolio is taken into accounts, raising the question-on BRICS competitiveness. This paper has come up with the focuses on why the mighty BRICS matters, and the main market and policy developments that is relevant from both a BRICS financial stability and integration perspective. The present paper reflects possible market and policy developments, global alliances, implications and trade relationship solutions.
\end{abstract}

\section{Keywords}

BRICS, Integration, Alliances, Competitiveness, Trade

Subject Areas: Economics, Politics

\section{Introduction}

BRICS is the acronym for an association of five major emerging national economies: Brazil, Russia, India, China and South Africa [1]. Figure 1 illustrates the geographical locations of BRICS nations in world map and Table 1 shows the economic data of five newly industrialized countries with fast growing economies which can have significant influence on regional affairs. BRICS focused on how to link their development agendas for expanding room for practical cooperation, and facilitating the development and prosperity of the whole Eurasian

"Corresponding author.

How to cite this paper: Karn, A.L. and Karna, R.K. (2016) Union Is Strength: Whether BRICS Is Boon or Curse in Perspective of Global Financial and Economic Periphery. Open Access Library Journal, 3: e2697.

http://dx.doi.org/10.4236/oalib.1102697 
(Brazil, Russia, India, China, and South Africa)

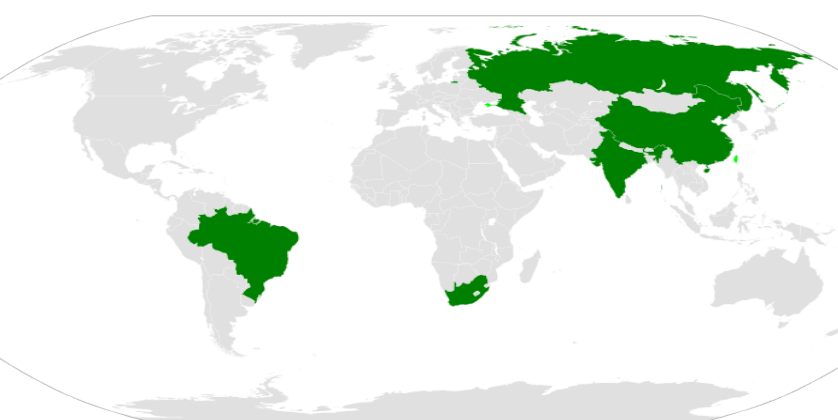

Figure 1. BRICS-in World map.

Table 1. Economic data is sourced from the International Monetary Fund, Current as of 2015, and is given in US dollars.

\begin{tabular}{|c|c|c|c|c|c|c|}
\hline Country & $\begin{array}{l}\text { GDP Growth } \\
\text { (2015) }\end{array}$ & $\begin{array}{l}\text { Foreign Exchange } \\
\text { Reserves (2015) }\end{array}$ & $\begin{array}{l}\text { Government } \\
\text { spending }\end{array}$ & Exports & Imports & "HDI \\
\hline Brazil & $\boldsymbol{V}-3.5 \%$ & $\$ 362,744$ bn & $\$ 846.6$ bn & $\$ 396.0$ bn & $\$ 278.8$ bn & 0.755 (high) \\
\hline Russia & $\boldsymbol{V}-2.7 \%$ & $\$ 358,500$ bn & $\$ 414.0$ bn & $\$ 542.5$ bn & $\$ 358.1$ bn & 0.798 (high) \\
\hline India & $\mathbf{A} 7.5 \%$ & $\$ 352,131$ bn & $\$ 616.0$ bn & $\$ 462.21$ bn & $\$ 500.3$ bn & 0.609 (medium) \\
\hline China & $\mathbf{A} 6.8 \%$ & $\$ 3,899,285$ bn & $\$ 2,031.0$ bn & $\$ 2,021.0$ bn & $\$ 1,780.0$ bn & 0.727 (high) \\
\hline South Africa & $\mathbf{A} 1 \%$ & $\$ 47,190$ bn & $\$ 95.27$ bn & $\$ 101.2$ bn & $\$ 106.8$ bn & 0.666 (medium) \\
\hline
\end{tabular}

${ }^{*}$ HDI = Human Development Index.

continent. The BRICS New Development Bank (NDB) and the Contingent Reserve Arrangement (CRA) are expected to act as powerful instruments for financing infrastructure investment and sustainable development projects in the BRICS, and other developing countries and emerging market economies, environmental and social responsibility initiatives driven by improvements to financial market regulations

Their "New Development Bank" has been seen as a challenge to the Washington-based International Monetary Fund and the World Bank. However it's a complement, instead of a challenge, to existing international institutions [2].

The opportunity for sustainable development provided by credit provision in the BRICS countries is huge: in 2012, their combined credit volumes exceeded US\$13.8 trillion, equivalent to roughly two-thirds of Western European or North American credit volumes. Statistics released by the International Monetary Fund show that in the past decade, the five BRICS nations contributed more than 50 percent to the world growth [3]. By 2030, the bloc is expected to see higher growth rates than most developed countries, and the most emerging economies. A Goldman Sachs report estimates that by 2020, the proportion of consumption by BRICS to the world total, will reach as high as 62 percent, from the current 23 percent [4].

\section{b. Why the Mighty BRICS Matter?}

-For the diversification of the BRICS products market by moving towards an eventual BRICS Free Trade Zone.

-For cyber security, cooperation on outer space, peace and conflict treaties, a proposal on planetary defense, a new agreement on non-aggression and peaceful co-existence, non-proliferation arrangements around new technologies and even a new arms control and export control regime.

-For critical partner in the Asian century.

\section{c. BRICS and the World}

BRICS should employ a multifaceted foreign policy approach. It must be characterized by growing economic ties; the pursuit of friendly relations with all countries; the protection of regional domestic stability and control; and the promotion of regional stability in support of BRICS regional economic, political, and security priorities.

\section{d. Core Observation "BRICS need Competitiveness"}

This data in Figure 2 showed that in US dollar terms the total value of each BRICS nation export was falling. 
Worse, the export Brazil, India, Russia and South Africa have essentially stagnated over the past four years or deteriorated significantly. "According to one of 'beyondbrics blog' comment-Brazil is not growing anymore, Russia is in crisis, India drags along with mediocre growth year after year and South Africa has been replaced by Nigeria as the largest African economy. China is no more growing at double digit and their official growth figures at 7 percent aren't taking serious by many anymore. It's obvious these countries lost competiveness. Soybeans price went down, and it hurts Brazil, Oil price went down and it hurts Russia, China's no more competitive and other nations are biting its textile and manufacturing industries. I am not sure this acronym of BRICS is valid anymore." If the Substantial depreciations of the BRICS national currencies over the past years are also taken in to consideration, then the competitiveness of BRICS becomes real issue [5].

\section{BRICS Financial Stability and Integration}

Developments in BRICS trigger numerous questions as to what one should expect the new market and institutional equilibrium to look like. What will be the capital structure of financial institutions on the one hand and of non-financial companies on the other? How much will funding structures and financial leverage continue to differ from one country to another even within a more complete financial market? What is the emerging optimal benchmark portfolio that banks, insurers, other financial institutions should target in order to optimally diversify risks to their assets and liabilities? What effective hedging instruments will be available to financial institutions, and private households? How much of these instruments are needed and how will they be accounted for?

\subsection{Governance and Accountability in BRICS's Financial System}

\section{a. Capital flows into and out of emerging markets}

Capital flows in and out of emerging market economies (EMEs) impact financial stability, In general, an acceleration of foreign (portfolio) capital flows quickly raise financial stability concerns in EMEs for a number of reasons. First, portfolio capital tends to flow into asset classes that can quickly absorb the inflow with the risk of creating asset price bubbles. Second, lack of consensus in EM societies how to distribute the benefits from higher growth can quickly translate into political instability. Third, the larger the stock of foreign assets or liabilities becomes, the more the country becomes exposed to a sudden stop or even reversal of capital flows. Emerging market bond markets expected to react immediately to the shift in market expectations [6] (Chart 1).

Going forward as now BRICS, the importance of cross-border alliances between economies is expected to grow even further due to the growing importance of multi-geography and multi-asset trading. Given the regulatory and political obstacles that cross-border mergers and acquisitions might face, exchanges can be expected to increasingly leverage innovative alliances such as the establishment of network linkages and partnerships in research and development and data sharing among BRICS. From a business perspective, these global alliances are expected to have a significant impact on the bottom lines of financial intermediaries [7]. Let's see Market developments in equity markets -Equity markets were particularly impacted by the crisis. BRICS must conduct standardization of regulatory and IT platforms of trading entering into a partnership/alliance, from prosperity perspective (Chart 2).

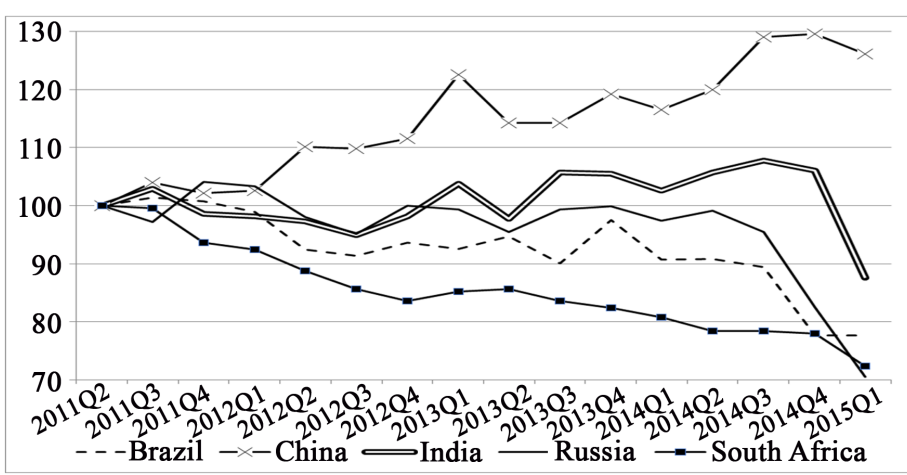

Figure 2. Exports of leading trading nations in BRICS (SOURCE-OECD. For each series the data was normalized to 100 in Q2 2011.) 

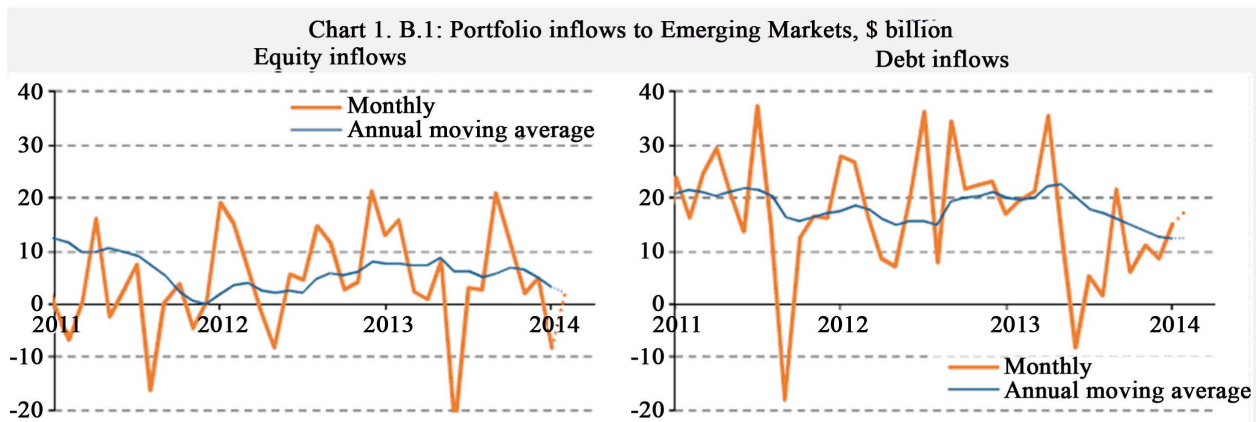

Source: Institution of International Finance and own calculations.

Chart 1. Capital flows to emerging markets (source EU report 2013).
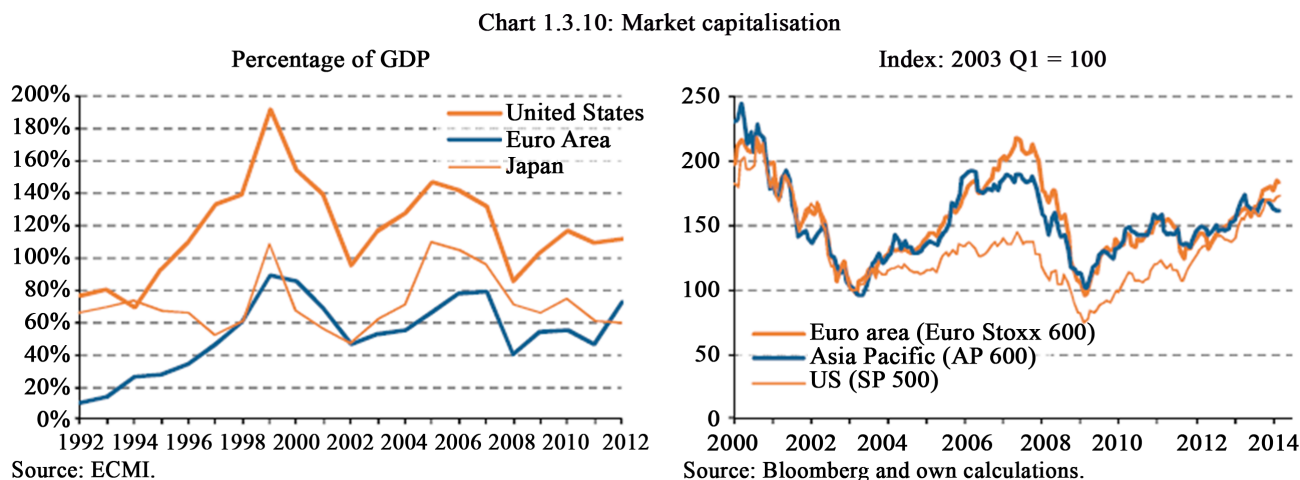

Chart 2. Market capitalization (Source EU 2013).

\section{b. Reforms in the financial sector}

On the other hand, banks are among the most important players themselves in the most dynamic segments of an evolving financial system. Reflecting this multitude of questions financial integration needs possible integration process. Businesses, governments and households need to finance their activities. The real question is how economic sectors are financed? For the government and financial corporation's the use of bonds is a significant source of funding. The real economy finances its activity mainly through bank loans. Market integration in the retail segment takes usually the form of cross-border ownership of banking assets. There is always a chance that Cross-border interbank lending continued to be affected by the crisis [8]. Hence by analyzing the implications of the crisis for cross-border provision of credit through branches and subsidiaries and mitigating its potential negative effects must be the main goal of the BRICS.

c. Creating a "banking union" set up as BRICS agency to strengthen currency exchange for trading

The Banking Union will be a vital part of a BRICS. It is instrumental for the BRICS and, in particular, the BRICS area, where the banking sector are likely to play a central role in financing the real economy.

The objectives of the Banking Union will be: to increase financial stability while minimizing costs to taxpayers, restore confidence in the financial sector and reduce market fragmentation, and ultimately contributing to economic recovery.

The Banking Union will achieve these objectives by (i) generating a higher quality of financial integration and thereby reverse the fragmentation of the internal market; (ii) ensuring the impartial application of high and common standards of prudential supervision and for the resolution of banks, and (iii) help ensuring the smooth transmission of monetary policy and breaking the link between sovereign and bank debt, sparing bail outs with public money; reinforcing financial stability and restoring confidence in the sector, fostering recovery.

\section{d. Building new rules for the global financial system}

Like: fundamental step towards the completion of the Banking network; on shadow Banking as needing better monitoring; on insurance supervision; transparency and annual reports of organizations; prevention of the use of the financial system for the purpose of money laundering and terrorist financing; a set of minimum principlebased rules to strengthen administrative sanctions and a requirement for them to coordinate actions when dealing 
with cross-border cases; a new investment fund framework designed for investors who want to put money into companies and projects for long and short terms; the use of low cost internet payment services; payment transactions ease; Market Abuse Regulation; systems to minimize distorted incentives for banks; package of measures to channel funds to the real economy, in particular to long-term investment promoting cross-border activity and helping long-term investment.

e. Shadow banking

What will be the role of regulated BRICS banks in the different shadow banking activities? Figure 3 illustrates the shadow banking at a glance. What regulatory measures do the BRICS plan to take in the area of shadow banking and additional measures required?

BRICS focus on the system as a whole would be useful, in particular to aid macro prudential surveillance and monitoring, to help regulators keep up with the fast pace of innovation, and to help understand where the future risks are likely to arise and build up:

-Limiting spill-overs between shadow banking entities and regulated banks;

-Reducing the vulnerability of money market funds to runs;

-Identifying and controlling the systemic risks from new and unregulated shadow banking entities;

-Assessing and aligning incentives associated with securitisation activities; and

-Dampening the risks and procyclicality associated with securities lending and repo

In the derivatives dynamics in BRICS bank, what do financial statements reveal about derivatives? Do derivatives accounted for on the balance sheet provide useful information to investors on the financial position of a given bank? Do aggregated figures on derivatives inform or mislead investors on bank stability? How can changes in the fair value of derivatives play themselves out in terms of balance sheet stability?

\subsection{Country-Specific Factors}

a. Inflation: Rising inflation decreases the value of debt and makes it cheaper for a firm. Also, tax deductions from debt financing are more valuable when inflation is expected to be higher. Indeed, the trade-off theory predicts and Frank and Goyal (2009) find a positive relation between inflation and leverage [9].

b. GDP Growth/unemployment/output gap: During times of economic prosperity collateral values increase and debt financing becomes easier. Agency problems between firms and investors become more severe in economic downturns. Thus, leverage should be procyclical. However, internal funds of firms generally increase in economic expansion so that according to the pecking order theory firms might make less use of debt financing. Frank and Goyal (2009) find a positive relation while Köksal et al. (2013) find a negative one [10].

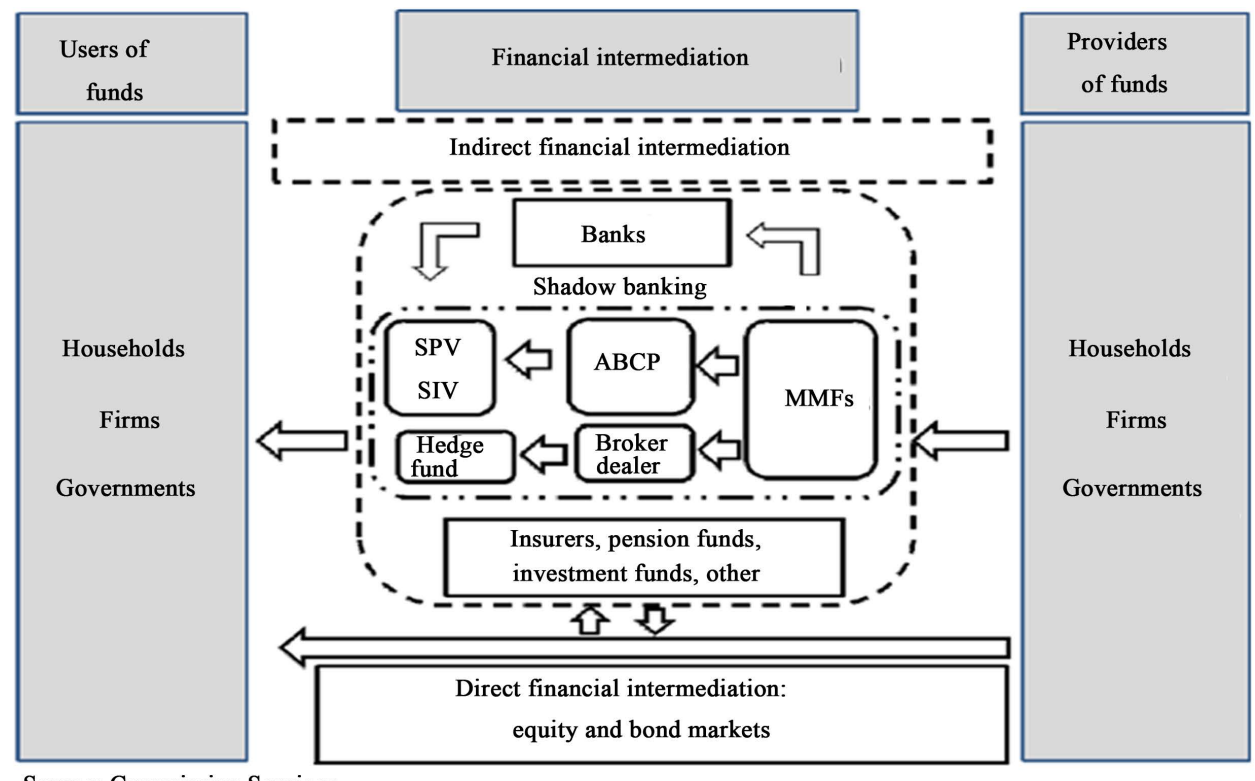

Figure 3. Stylized overview of the financial intermediation role of the financial system. 
c. Stock Prices: We also want to take into consideration how expensive equity for public firms is. Thus, we include Standard \& Poor's Global Equity Indices, which measure the performance of various stock exchanges around the world. Welch (2004) and Frank and Goyal (2009) argue that the effect of changing stock prices on capital structure may reflect overall growth prospects, relative price changes in asset classes or differences in agency costs [11] [12]. According to the market timing theory, equity issuance is pro-cyclical while debt financing is counter-cyclical. Firms may take advantage of mispricing in stock markets to reduce their capital costs. Thus, capital structure theories predict that stock price development and leverage ratios are negatively related.

\section{Implications}

\subsection{Global Alliances (BRICS Perspective)}

The global financial economic' ecosystem is currently in a state of flux. Increased volatility, higher reporting obligations, and competitive pressure are resulting in an exponential rise in market information volume. Cost and scale considerations and competitive pressure are forcing intermediaries to forge innovative global alliances. Evolving governance demands for multi-asset and multi-geography trading, the rise of BRICS, and regulatory pressure will drive increased investment in co-operation and infrastructure upgrades. All of these structural changes are expected to have a profound impact on the global finance and technology strategies in the coming years.

Establishing cross-border alliances is expected to be a technology-intensive exercise along with regulatory body policies. Economies will have to assess their networking and data-management capabilities, and may have to bring about changes/upgrades in order to meet the requirements that their cross-border alliances might impose. Standardization of regulatory and IT platforms of trading entering into a partnership/alliance may have to be carried out, which will require additional investments from prosperity perspective.

\subsection{BRICS Trade and Economic Relationship and Agriculture Trade Futures}

Russia is the world's third largest importer of agricultural commodities, particularly poultry, dairy, and fruits and vegetables. With just $2 \%$ of the world's population, Russia consumes close to $20 \%$ of the world's poultry. Brazil among BRICS as shown in Figure 4 and Figure 5 is the largest agricultural exporter among its group.

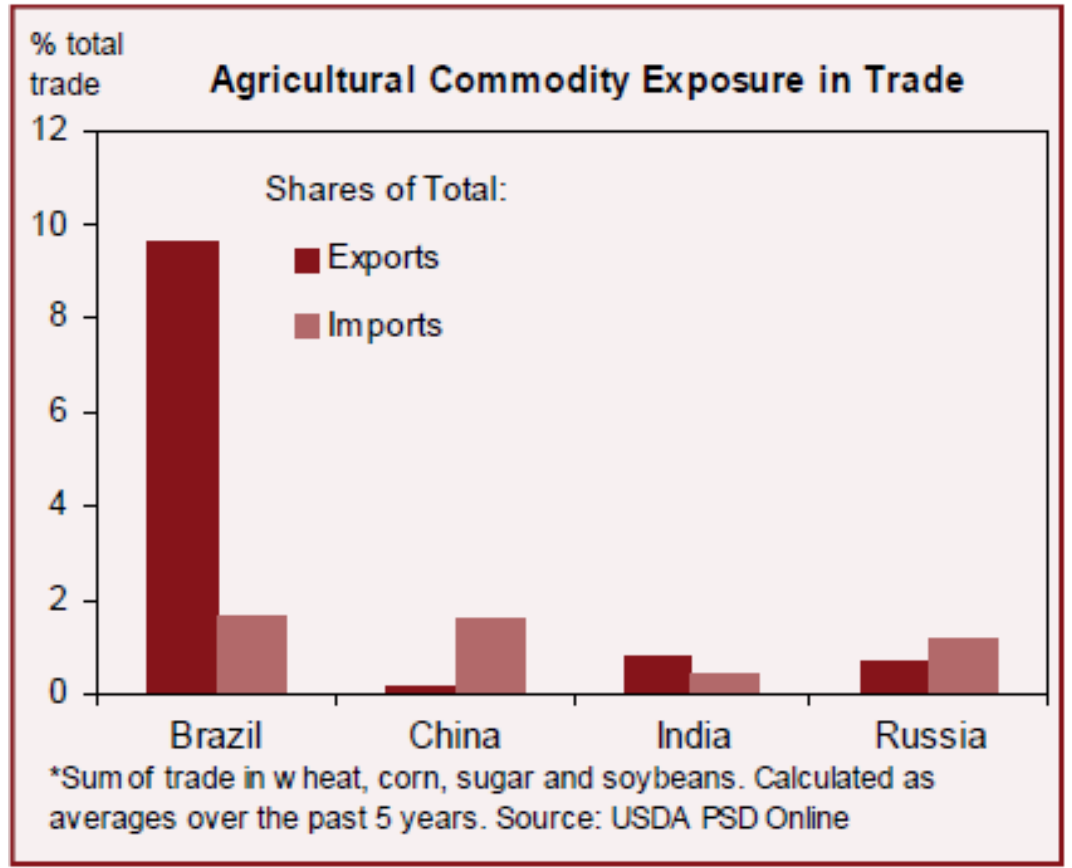

Figure 4. Brazil is the largest agricultural exporter than China, India and Russia. 


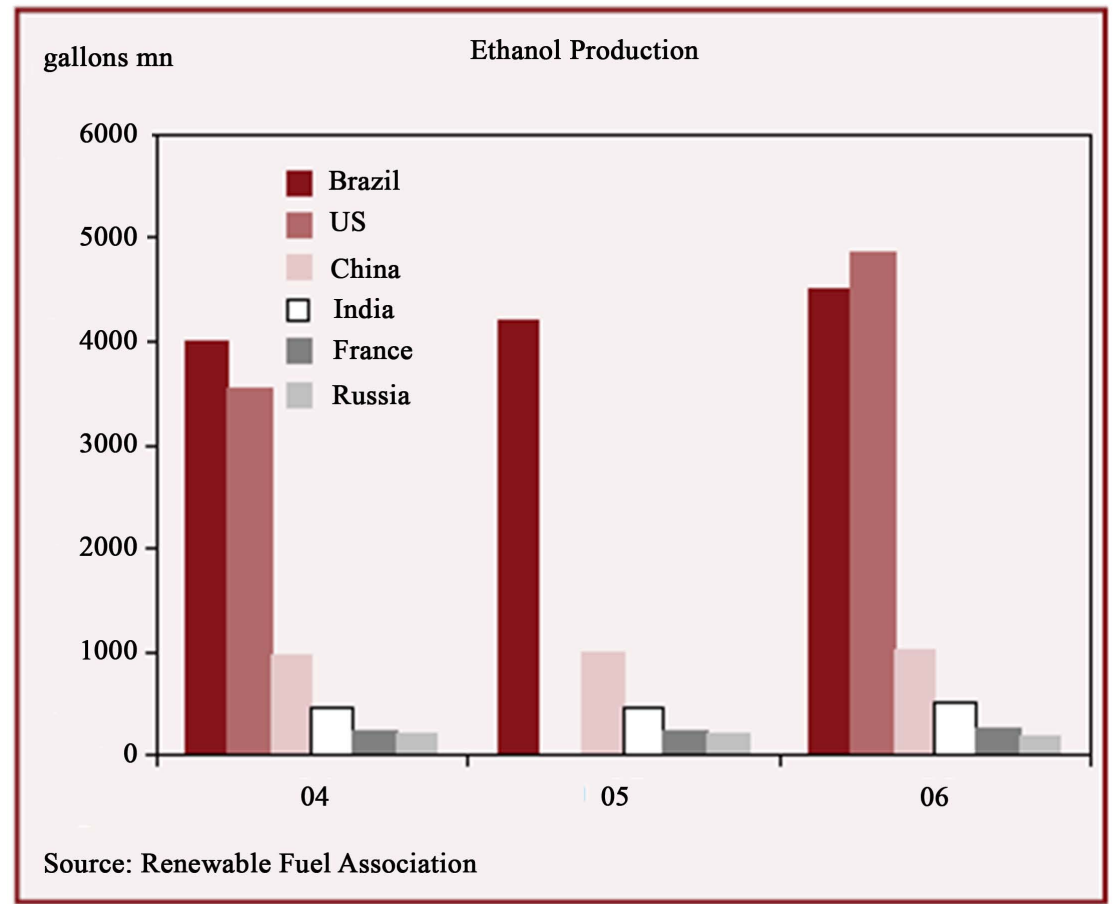

Figure 5. Brazil among BRICS are among top global producers of ethanol.

China also ranks among the top ten importers of agricultural commodities. It remains the largest importer of cotton, the critical raw material for its textile exports. But these imports should fall over time as China export industry continues to climb the value chain. The OECD and FAO estimate that China will become the largest importer of oilseed meals and consolidate its position in imports of oils and oilseed as biofuel production expands.

Growing demand from BRICS nations may support exporters in certain sectors of the rest of the world economy, such as aerospace, the auto industry, and agricultural products. BRICS can continue to intervene in foreign exchange markets to keep its currency undervalued. Such interventions, combined with Brics's subsidies to exporting industries, can help BRICS accumulate the largest foreign currency reserves and might continue to diversify their foreign exchange assets. In sense of investment, First possibility is, BRICS manufacturing companies should invest within and overseas in order to establish international networks and globally recognized brands. Second, BRICS companies should invest in research and development within and outside of BRICS nations. Lastly, the plan set goals for shifting acquisitions toward sectors that promote a high-tech economy.

BRICS must transform into an urban society with a growing middle class first, per capita food consumption automatically will rise and, with it, the demand for higher-protein diets-a demand that developed economy farmers are well positioned to fill. In trade, based on scientific analysis BRICS nations should then only adopt excessive subsidies; government control over import quotas; discriminatory taxes; and sanitary and phytosanitary restrictions on Imports exports of higher value added products within and outside BRICS. These measures may contribute to a balanced food trade and should not be particularly damaging to bloc nations, in terms of resources, quality, and efficiency.

\section{Suggesting Innovative Projects}

a. The Mini Stimulus_-stimulus packages—aimed at boosting the slowing economy.

b. Further Developments in Internationalization of BRICS tradable currencies. By developing an offshore market for these currencies as a precursor to allowing global firms, banks, and asset managers access to its domestic markets.

c. Capital Account Liberalization. The primary motive was to attract foreign investors, and indirect way to stimulate a sluggish economy. 
d. Qualified Foreign Institutional Investor program-Allows investors to bring U.S. dollars onshore and exchange them into BRICS tradable currencies, Qualified Foreign Institutional Investor program allows selected institutions to raise BRICS tradable currencies offshore as well (like in China RMB) [13].

\section{Conclusions}

The World Needs Better Economic BRICS to operate in a more transparent environment; to see a quicker reduction in global imbalances, a fairer value of many currencies, and some credible measures to halt the erosion of our environment. BRICS's nations trade surplus with the outside economy in goods helps to manipulate the value of their currency, to achieve a competitive advantage with the other states. Mercantilist policies then might only be said goal oriented. BRICS has potential to success in transitioning toward a consumption-led growth model as well as on massive infrastructure projects to boost economic growth. Consequently, BRICS's high investment levels can led to effective capacity in multiple industries, including steelmaking, shipbuilding, and solar panel manufacturing. BRICS investors may primarily target those sectors like Strategic and Emerging Industries, Energy and services. High-end manufacturing should be another important destination for BRICS's investments, particularly when measured in terms of the number rather than the value of deals. BRICS nations have complete potential of fostering globally competitive agribusinesses, in the process of becoming an active acquirer of agricultural assets overseas. Indeed BRICS is a boon to this globalised fragmented market.

Eventually, why BRICS will have so much success in trade? This will relate both to the speed of its urbanization and its ability to attract large amounts of FDI. The international community needs to support and encourage BRICs. If this occurs, then we are all likely to benefit for a long time into the future from a repeat of the strong growth/low inflation environment experienced over the past decade. Threats: In absolute terms India will remain a low-income country for several decades, with per capita incomes well below its BRIC peers. But if it can fulfill its growth potential, it can become a motor for the BRICS and world economy and a key contributor to generating spending growth. This is also one true explanation to "why mighty BRICS matters?"

\section{Conflict of Interests}

The authors declare that there is no conflict of interests regarding the publications of this research paper.

\section{References}

[1] BRICS (2015) https://en.wikipedia.org/wiki/BRICS

[2] Li, D.X. (2015) Chief Economist of Yingda Securities, Told AFP. http://www.atozforex.com/news/brics-new-development-bank/

[3] BRICS Summit Will Coordinate Cooperation. China Daily. http://www.chinadaily.com.cn/opinion/2015-07/09/content_21228742.htm

[4] Bourne, C.D. (2015) Thought Leadership as a Trust Strategy in Global Markets: Goldman Sachs' Promotion of the "BRICs" in the Marketplace of Ideas. Journal of Public Relations Research, 27, 322-336. http://dx.doi.org/10.1080/1062726X.2015.1027772

[5] Xu, D. (2015) Financial Statism as an Alternative Interventionist Approach in Developing International Financial Centres (IFCs): The Case of Shanghai since the 1990s. Doctoral Dissertation, UCL (University College London), London.

[6] Mihaljek, D. (2008) The Financial Stability Implications of Increased Capital Flows for Emerging Market Economies. BIS Papers, 44, 11-44.

[7] EU Commission (2012) European Financial Stability and Integration Report 2012. Brussels. http://ec.europa.eu/internal_market/economic_analysis/docs/efsir/130425_efsir-2012_en.pdf

[8] Greenspan, A. (1998) The Current Asian Crisis and The Dynamics of International Finance. Testimony of Chairman Alan Greenspan before the Committee on Foreign Relations, Washington DC.

[9] Frank, M.Z. and Goyal, V.K. (2009) Capital Structure Decisions: Which Factors Are Reliably Important? Financial Management, 38, 1-37. http://dx.doi.org/10.1111/j.1755-053X.2009.01026.x

[10] Bülent, K., Cüneyt, O. and Arif, O. (2013) Determinants of Capital Structure: Evidence from a Major Emerging Market Economy (No. 48415). University Library of Munich, Munich.

[11] DeAngelo, H. and Stulz, R.M. (2015) Liquid-Claim Production, Risk Management, and Bank Capital Structure: Why High Leverage Is Optimal for Banks. Journal of Financial Economics, 116, 219-236. 
http://wps.aw.com/wps/media/objects/222/227412/ebook/ch11/chapter11.pdf http://dx.doi.org/10.1016/j.jfineco.2014.11.011

[12] Fernandez, P. (2007) A More Realistic Valuation: APV and WACC with Constant Book Leverage Ratio.

[13] Southerland, M., Koch-Weser, I. and Zhang, A. (2014) China-India Relations: Tensions Persist Despite Growing Cooperation. US-China Economic and Security Review Commission Staff Report, Washington DC.

\section{Warmly welcome your paper submission to OALib Journal!}

- Publication on a daily basis

- 9 subject areas of science, technology and medicine

- Fair and rigorous peer-review system

- Fast publication process

- Article promotion in various social networking sites (LinkedIn, Facebook, Twitter, etc.)

- Widely-targeted and multidisciplinary audience to read your research

Submit Your Paper Online: Click Here to Submit

Contact Us: service@oalib.com 